\title{
ZNACZENIE POSIADANIA DOJRZAŁEJ OSOBOWOŚCI U OSÓB PRZYGOTOWUJĄCYCH SIĘ DO MAŁŻEŃSTWA - SZKIC PSYCHOLOGICZNY Z UWZGLĘDNIENIEM WAZTKU PASTORALNEGO
}

$\mathrm{W}$ artykule pt. Koncepcja dojrzałej osobowości oraz jej wyznaczniki - prolog do rozważań w kontekście osób przygotowujacych się do małżeństwa, opublikowanym w „Teologia i Człowiek”, zostało scharakteryzowane pojęcie osobowości. Ze względu na odmienność definiowania tego terminu w zależności od nurtu psychologicznego, skupiono się tylko na podejściu psychologii humanistycznej. Zaprezentowano osobowość w kontekście cechowym, bazując na myśli Gordona W. Allporta i Raymonda B. Cattella. Scharakteryzowano również i wymieniono wyznaczniki dojrzałej, dobrze przystosowanej osobowości.

* Ks. dr Sławomir Tykarski jest adiunktem w Katedrze Teologii Praktycznej Wydziału Teologicznego UMK (tykarek@gmail.com).

${ }^{1}$ Odsyłam do artykułu S. Tykarski, Koncepcja dojrzałej osobowości oraz jej wyznaczniki jako prolog do rozważań w kontekście osób przygotowujących się do małżeństwa - szkic teoretyczny, „Teologia i Człowiek” 39 (2017) 3, s. 183-195 
Niniejszy artykuł jest drugą częścią swoistego dyptyku, opisując znaczenie posiadania dojrzałej osobowość u osób przygotowujących się do małżeństwa. Ukazane zostaną również negatywne konsekwencje mające wpływ na relacje małżeńskie, które wynikają z posiadania niedojrzałej osobowości. Nie zabraknie też wątku pastoralnego, ukazującego rolę Kościoła w wychowaniu do dojrzałej osobowości, i zaprezentowania dezyderat, jakie mógłby podjąć ku realizacji tego zadania.

\section{PRZEŁOŻENIE POSIADANIA (NIE)DOJRZAŁEJ OSOBOWOŚCl NA ŻYCIE MAŁŻEŃSKIE}

Posiadanie dojrzałej osobowości lub jej brak ma istotne znaczenie dla życia małżeńskiego. Na podstawie przytoczonych wyznaczników konstytuujących dojrzałą osobowość można dokonać opisu, w jaki sposób realizują się one w konkretnych zachowaniach osób jako małżonków. Bazując na koncepcji Cattella, ze względu na ich mnogość, opis ten nie będzie odnosił się do każdego z nich, lecz nakreśli bardziej ogólne tendencje, które wyznaczył Allport. Mimo że proponuje on poszczególne kryteria, to w przełożeniu na życie małżeńskie nie zawsze można dokonać ostrego podziału. Niekiedy kryteria są ze sobą powiązane i mieszają się, stąd podane poniżej przykłady mogą pasować do różnych wyznaczników dojrzałej osobowości. Ponadto niniejsze opracowanie, mając zawężony zakres, przyjmuje charakter szkicu problematyki i niemożliwe jest uwzględnienie wszystkich przypadków, okoliczności i implikacji z nich wypływających.

Człowiek z dojrzałą osobowością potrafi koncentrować się na problemach, nie boi się ich i potrafi je rozwiązywać. Ma to szczególne znaczenie w życiu małżeńskim. Małżonkowie nie uciekają od problemów, nie udają, że ich nie ma. Dotyczy to zarówno problemów zewnętrznych, jak i wewnętrznych. Pierwsze mogą dotyczyć spraw zawodowych lub socjalnych. Małżonek potrafi zabezpieczyć byt rodzinie, nie stroni od pracy, podejmuje ją, nie szuka wygodnictwa. Problemy wewnętrzne zaś odnoszą się do relacji i skupiają się na organizacji życia domowego, kształtowania relacji, wyjaśniania kwestii spornych, rozwiązywania konfliktów². Mąż

\footnotetext{
${ }^{2}$ Więcej na temat rozwiązywania konfliktów małżeńskich zob. S. Tykarski,
} 
czy żona nie zbywają współmałżonka, odkładając rozmowę na trudne tematy, nie bagatelizują ich znaczenia i nie wycofują się, mówiąc: „Daj mi spokój. Masz problem, to rozwiąż go sam”, „Nie obchodzi mnie to”, „Lepiej nie ruszać tej kwestii”. Człowiek dojrzały wychodzi problemom naprzeciw, sprawdzając siebie $\mathrm{w}$ konfrontacji z nimi. Ma to przełożenie na kształtowanie zaradności, podnosi morale i wartość osoby. Kandydaci do małżeństwa powinni zwrócić uwagę, jak partner zachowuje się w sytuacjach problemowych, czy stara się stawić im czoła, czy ucieka lub ceduje rozwiązanie na kogoś innego.

Wyznacznikiem dojrzałej osobowości u kandydata do małżeństwa jest posiadanie przez niego bliskiej więzi z innymi osobami. Są to uczucia miłości i przyjaźni. Relacje te cechuje życzliwość, okazywanie ciepła, przywiązania, empatii, akceptacji powiązanej również z tolerancją wad, których nie są pozbawione osoby bliskie. Kandydat do małżeństwa winien posiadać umiejętność tworzenia bliskich więzi z otoczeniem. Zastanawiające jest, gdy jedna strona orientuje się, że jej wybranek nie prowadzi życia towarzyskiego, że nie posiada osób bliskich, że paradoksalnie pogłębione życie społeczne wyczerpuje tylko na swojej osobie. Niewłaściwa jest mentalność wyrażająca się w stwierdzeniu o partnerze, że ,jest on całym światem", i niebezpieczne jest, gdy wybranek izoluje swojego partnera od jego znajomych czy przyjaciół, ograniczając i wyznaczając mu kontakty towarzyskie. Może łączyć się z tym wątek zazdrości. Jeśli zazdrość partnera jest tak silna, że skutkuje kontrolą nad życiem drugiej strony, wyznaczaniem jej towarzystwa, czasu i miejsc spotkań ze znajomymi, sprawdzaniem prawdomówności, świadczyć to może o braku dojrzałości i pewnego rodzaju fiksacji, a nie o trosce i opiekuńczości, jak może być mylnie odbierana. Tak więc

zdolność do wchodzenia w bliskie i głębokie relacje osobowe jest oznaką dojrzałej i prawidłowo rozwiniętej osobowości, tak jak z kolei niezdolność

Negocjacje jako sposób rozwiązywanie konfliktów małżeńskich i rodzinnych, „Teologia i Człowiek" 30 (2015) 2, s. 151-170.

3 Ze względu na uproszczony styl autor nie odmienia przez osoby podawanych przykładowych wypowiedzi, które mogą odnosić się zarówno do mężczyzn, jak i kobiet. Dlatego czytelnik nie powinien się sugerować konkretną formą, ale pamiętać, że przykłady mają swoje przełożenie na zachowanie i odczuwanie mężów i żon. 
do nawiązywania takich relacji jest oznaką niedojrzałości psychicznej, a nawet wrodzonej głębszej anomalii psychicznej o typie psychopatii. Zdolność do nawiązywania bliskich, głębokich uczuciowych więzi z drugimi jest koniecznym warunkiem do tworzenia różnego typu wspólnot, przede wszystkim wspólnoty małżeńskiej i rodzinnej, a także innych wspólnot łączących ludzi. Życie we wspólnocie jest koniecznym kontekstem życia osobowego, a zarazem sprawdzianem dojrzałości osobowej człowieka ${ }^{4}$.

Emocjonalna dojrzałość ma istotne przełożenia na zachowania kandydata do małżeństwa lub samego małżonka. Dojrzała sfera emocjonalna pozwala nawiązywać trwałe i pozytywne kontakty uczuciowe z innymi ludźmi. Jednostka, która ma deficyty w tej materii, nie będzie potrafiła nawiązywać głębszych relacji emocjonalnych, więzi będą powierzchowne, a dokonywane wybory podpierane zmiennymi stanami emocjonalnymi pod wpływem chwili. Może być także zahamowana w okazywaniu uczuć, z czym trudno będzie pogodzić się współmałżonkowi, odczuwającemu braki w tym względzie. Może nie czuć się kochanym, nie będzie wiedział, ile znaczy dla partnera, co będzie przejawiać się w sformułowaniach typu: "Już dawno nie mówisz mi, że mnie kochasz”, „Nie okazujesz mi uczuć,, "Czuję się zaniedbana”. Dochodzi wówczas do asymetrii emocjonalnej, polegającej na wzajemnym, nierównomiernym obdarzaniu uczuciami. Jest to sytuacja, w której jeden z małżonków informuje o swoich uczuciach przez czułe zwroty, gesty, czyny, drugi zaś nie odpowiada tym samym - jest powściągliwy, chłodny, zamknięty. Brak gratyfikacji emocjonalnej powiązanej z nieodwzajemnieniem starań wobec współmałżonka może spowodować, że ten poczuje się niedoceniony, odtrącony, zlekceważony. To z kolei może stać się przyczyną jego zdystansowania i zaprzestania okazywania ekspresji uczuciowej. W ten sposób zachodzi realne zagrożenie oddalenia od siebie małżonków i rozluźnienia więzi.

Fakt zaangażowania uczuciowego obojga małżonków jest warunkiem prawie koniecznym (90\% małżeństw udanych przejawia obopólne zaangażowanie) do zaistnienia małżeństwa udanego. Siła związku między jakością małżeństwa i zaangażowaniem się uczuciowym małżonków jest bardzo wysoka. Nie ma małżeństw udanych, w których przynajmniej jedna ze stron nie przejawiałaby zaangażowania emocjonalnego [...].

${ }^{4}$ M. Wolicki, Dojrzała osobowość. Dojrzałe sumienie, Wrocław 2000, s. 28. 
Pozytywne nastawienie wobec siebie przyczynia się do tego, że małżonkowie chętnie przebywają razem, są sobie życzliwi, zdobywają się na wyrozumiałość, potrafią wybaczyć różne słabości i mimo występowania napięć dochodzą na drodze dialogu do porozumienia 5 .

Natomiast brak zaangażowania emocjonalnego $\mathrm{z}$ równoczesnym niedocenianiem (a nawet wyśmianiem) przejawów uczuciowości współmałżonka zaburza kondycję związku. Jeśli zatem kandydaci do małżeństwa spostrzegają u swoich partnerów oziębłość emocjonalną, to w przyszłości życia małżeńskiego może stanowić to niemały problem.

Inny wyznacznik dojrzałej emocjonalności polega na tym, iż osoba pomimo przeżywanych stanów frustracji, niepokoju, braku równowagi uczuciowej potrafi funkcjonować, narzucając sobie dyscyplinę i samokontrolę. oraz podporządkowuje uczucia niższe wyższym. Ma to niebagatelne znaczenie w życiu małżeńskim, mąż lub żona z dojrzałą emocjonalnością będzie bowiem potrafił zrezygnować ze swoich potrzeb na rzecz dobra drugiej strony. Wiąże się to $\mathrm{z}$ rozwojem postaw i uczuć wyższych, to znaczy altruistycznych. Tylko człowiek dojrzały potrafi ponieść ofiarę na rzecz wyższego dobra ${ }^{6}$. W przeciwnym wypadku małżonek z niedojrzałą sferą emocjonalną będzie stawiał opór, gdy pojawią się okoliczności zagrażające realizowaniu jego potrzeb i pragnień. Nieumiejętność ponoszenia ofiary może się odzwierciedlić w niechęci do podejmowania obowiązków wynikających z roli rodzicielskiej. Szczególnie ujawnia się to u mężczyzn, na których dość często skarżą się żony, mówiąc, że ich mężowie nie interesują się wychowywaniem dzieci, nie troszczą się o nie, nie spędzają z nimi czasu, nie pomagają w obowiązkach szkolnych itp. Tacy mężowie bardziej są skupieni na sobie i cechują się egoizmem i egocentryzmem.

Osoba z niedojrzałą emocjonalnością często podlega nastrojom, wybuchom gniewu, niezadowolenia, obraża się. To zaś nie sprzyja poprawnej komunikacji. Stąd też w relacjach pojawiają się kłótnie, nieposzanowanie współmałżonka, ranienie słowami. Osoba cechująca się dojrzałą emocjonalnością nie chowa urazy, jest otwarta na pojednanie i dąży do niego. Doznane zranienia nie powodują śmiertelnej rany emocjonalnej,

5 J. Laskowski, Trwałość wspólnoty małżeńskiej. Studium socjopsychologiczne, Warszawa 1987, s. 168-169.

${ }^{6}$ Zob. P. K. Oleś, Psychologia człowieka dorosłego, Warszawa 2012, s. 251. 
a przeżywane porażki nie przeradzają się w klęski. Dojrzała jednostka potrafi żyć ze stanami smutku, przygnębienia i melancholii, a jej złe samopoczucie nie przekłada się na cierpienie innych.

Małżonek $\mathrm{z}$ dojrzałą emocjonalnością jest naturalny w swoim zachowaniu. Charakteryzuje go brak wszelkiego rodzaju sztuczności, dziwaczności, sztywności, teatralności - jego zachowanie jest spójne w życiu prywatnym, jak i towarzyskim. Nie ma różnych profili przybieranych w zależności od potrzeby sytuacji. Jego zachowanie jest kongruentne, tzn. pozbawione fałszywości powodującej, że dla otoczenia widnieje jako osoba miła, dobra, życzliwa, a w życiu domowym swoim zachowaniem zaprzecza tym cechom. Ponadto ma poczucie humoru powiązane ze zdolnością dystansowania się do samego siebie. Poczucie humoru wyrasta z realistycznej samooceny oraz z dostrzegania swoich słabości i śmieszności. To sztuka żartowania z siebie, a nie z ułomności drugiego człowieka.

Przykładem niedojrzałości emocjonalnej, stanowiącej podstawę równie niedojrzałej motywacji do zawarcia małżeństwa, jest ucieczka przed samotnością lub trudną atmosferą domu rodzinnego. Małżeństwo może być mylnie postrzegane jako rzeczywistość, dzięki której zostaną zrealizowane niespełnione potrzeby z dzieciństwa danego kandydata (na przykład zrekompensowanie słabych więzi emocjonalnych z rodzicami), ucieczka z jakiejś nieszczęśliwej dla siebie sytuacji, zabezpieczenie przed staropanieństwem lub starokawalerstwem. Oprócz tych przyczyn istnieje także zawarcie małżeństwa $z$ litości umotywowanej pragnieniem udzielenia pomocy osobie nieszczęśliwej, pokrzywdzonej, niezaradnej, kalekiej. Trwałość takiego małżeństwa jest zagrożona zwłaszcza wówczas, kiedy współmałżonek nie okazuje żadnej wdzięczności. Przykładem małżeństwa z litości jest także sytuacja, w której osoba o niskim poczuciu własnej wartości bierze za małżonka osobę wykazującą znaczny stopień bezradności w tym celu, by zaspokoić własne potrzeby emocjonalne. Poprzez sprawowanie nad nim opieki wzrasta poczucie wartości osoby, która ją zapewnia. Natomiast kiedy zależny współmałżonek zapragnie decydować o samym sobie, wówczas dochodzi do niebezpiecznego kryzysu, gdyż osoba udzielająca opieki traci dotychczasowy cel swojego życia w małżeństwie .

7 Zob. D. Field, Osobowości małżeńskie, Warszawa 1996, s. 54-68. 
Z dojrzałą osobowością wiąże się również wątek miłości, czyli zdolność do kochania i bycia kochanym. Dojrzały kandydat do małżeństwa potrafi przyjmować miłość od innych ludzi, jak i sam nią obdarowywać. Pierwszym środowiskiem, w którym człowiek otrzymuje miłość i uczy się ją dawać, jest rodzina. $Z$ tego powodu ważne jest, by kandydaci poznali rodzinę pochodzenia swojego partnera. Wówczas łatwiej jest dostrzec bądź zrozumieć ewentualne braki w umiejętności kochania i okazywania miłości u drugiej strony. Jest wówczas jeszcze czas na powzięcie środków zaradczych. Trzeba być również czujnym, by miłości nie utożsamiać z uczuciowych uniesieniem, emocjonalną ekscytacją, pod wpływem której podjęłoby się decyzję o zawarciu małżeństwa. Miłość ma swoje składniki i dynamikę, nie jest subiektywnym odczuciem czy prostą formą zauroczenia ${ }^{8}$. Również kandydaci muszą zwrócić uwagę, czy miłości nie mylą i nie utożsamiają z pożądaniem seksualnym lub erotyczną fascynacją, które nie mogą stanowić podstawy do tworzenia więzi małżeńskiej. Dojrzałość osobowa w tej kwestii odnosi się do umiejętności panowania nad sferą pożądliwości i kontrolą swoich popędów. Brak takiej zdolności może mieć przełożenie na przyszłe życie małżeńskie i pojawienie się nie-

${ }^{8}$ O składnikach, fazach i dynamice miłości zob. B. Wojciszke, Psychologia miłości, Gdańsk 2012.

„Miłości nie można utożsamiać z samym tylko uczuciem - które cechuje skończoność w czasie, przemijalność - lecz ma ona stawać się postawą czyli rzeczywistością stabilną. Na postawę zaś składają się komponenty takie jak: myślenie, działanie, uczucie. Postawa miłości w małżeństwie winna odznaczać się zatem współmyśleniem, współdziałaniem i współodczuwaniem, czyli przejawiać się na płaszczyznach: poznawczej (intelekt), behawioralnej (wola) i uczuciowej (emocjonalnej). [...] Jeśli między małżonkami występuje tylko podobieństwo na płaszczyźnie uczuć, to może się to okazać niewystarczalne do zbudowania trwałego związku. Uczucia mają w sobie pierwiastek przemijalności, dynamiki, to znaczy, że dziś mogą być, ale po pewnym czasie mogą zaniknąć albo ich intensywność może znacząco zmaleć. Jeśli narzeczeni lub małżonkowie będą opierać swój związek wyłącznie na uczuciach, to może zakończyć się on niepowodzeniem, z rozpadem związku włącznie. Oprócz wspólnych uczuć względem siebie, małżonkowie również powinni podobnie myśleć, zgadzać się w podstawowych kwestiach, posiadać spójny światopogląd oraz wspólnie działać, dokonywać wyborów, przedsięwzięć i wspierać się w ich wykonywaniu. Dopiero taka kompozycja, odznaczająca się dojrzałością, daje szanse na trwałość związku małżeńskiego. Budowanie zaś związku na samych tylko uczuciach jest przejawem niedojrzałości osobowej". S. Tykarski, Kryzys małżeński jako wyzwanie dla duszpasterstwa. Studium teologiczno-pastoralne, Toruń 2015, s. 156-158. 
porozumień na tle pożycia intymnego. Może dochodzić do nadużyć w tej mierze i traktowania współmałżonka przedmiotowo poprzez wykorzystywanie go do rozładowania napięcia seksualnego. Wówczas tak bardzo ważna i delikatna sfera może zostać sprowadzona do czystej fizyczności, będąc ogołocona z wymiaru duchowego. Współżycie małżeńskie będzie odgrywało funkcję narzędziową zamiast budować intymną więź łączącą małżonków. Ponadto osoba niepanująca nad swoimi popędami może domagać się współżycia bez uwzględnienia psychofizycznego samopoczucia współmałżonka. Odczuwając frustrację, że nie zostało zaspokojone jego pragnienie, może uciekać się do szantażu, grożąc zdradą (i w końcu się jej dopuścić) lub uciec do użycia siły i uzyskać kontakt seksualny poprzez gwałt małżeński".

Panowanie nad sobą nie wyczerpuje się tylko w sferze płciowej. Również umiejętność kontrolowania zażywania używek lub w ogóle zdolność z ich rezygnacji stają się potwierdzeniem posiadania dojrzałej osobowości. Dla kandydatów do małżeństwa sygnałem ostrzegawczym winny być zauważone u partnera symptomy wszelkiego rodzaju uzależnień od alkoholu, narkotyków, hazardu, telewizji, internetu, gier komputerowych. Zbagatelizowane objawy mogą mieć w późniejszym życiu małżeńskim poważne konsekwencje. Dla uzależnionego współmałżonka będzie liczyło się przede wszystkim zaspokojenie potrzeb związanych z nałogiem, a nie dobro członków rodziny. Przymykanie oka na przejawy uzależnień zauważone u partnera podczas znajomości przedślubnej i życzeniowe myślenie, że po ślubie się zmieni, już samo w sobie jest zachowaniem niedojrzałym.

Z dojrzałą osobowością wiąże się również realistyczne spostrzeganie rzeczywistości. Małżonkowie mają świadomość zobowiązań, jakie na nich ciążą; utrzymania rodziny, zabezpieczenia materialnego itp. Szczególne znaczenie ma u małżonków poczucie względnej autonomii społecznej, czyli niezależności od innych. Wiąże się to z samodzielnością,

9 Nupturienci winni poznać pogląd drugiej strony na temat wierności małżeńskiej. Już w czasie trwania znajomości przedślubnej, poprzez obserwację partnera, należy upewnić się, czy nie wykazuje on „zachowań ryzykownych” typu: wyzywającego zachowania w nawiązywaniu kontaktów z płcią przeciwną, kokieterii, flirtowania podczas spotkań towarzyskich, niebezpiecznych poufałości w słowach i gestach. Jeśli zdarzałyby się one, to istnieje niebezpieczeństwo powielania takich zachowań po zawarciu małżeństwa, co może skutkować zdradą małżeńską. 
niezależnością w podejmowaniu decyzji i wyborów życiowych ${ }^{10}$. Małżonkowie z niedojrzałą osobowością nie potrafią podejmować decyzji, stronią od tego, cedują je na męża czy żonę, co odbierane jest przez nich jako brak zainteresowania, zaangażowania czy wygodnictwo. Ponadto może wystąpić sytuacja uzależnienia swoich decyzji od innych osób - przeważnie od własnych rodziców (rodzica), rodzeństwa, przyjaciół. Może mieć to negatywne konsekwencje, będzie bowiem rodzić konflikty ze współmałżonkiem, który może częściej konsultować decyzje z osobami postronnymi niż z partnerem. Pojawia się także realne zagrożenie nieporozumień z teściami, których postrzegać się będzie jako wtrącających się w życie małżonków ${ }^{11}$.

Kolejny wyznacznik dojrzałej osobowości koreluje z samorozwojem (samorealizacją). Wiąże się to ze świadomością posiadania własnych zdolności i zalet oraz z ich rozwojem i wykorzystywaniem dla dobra innych. To świadome zarządzanie swoimi kompetencjami. Samorozwój wiąże się z posiadaniem takich cech, jak: ambicja, wytrwałość, sumienność, rzetelność, pracowitość, posiadanie zainteresowań, kreatywność. Jeśli kandydat do małżeństwa nie zna swoich mocnych stron, nie rozwija talentów, jest opieszały, leniwy, pozbawiony ambicji i celów, może mieć to istotne znaczenie w przyszłym życiu małżeńskim. Taka osoba może nie dbać o dobry status rodziny, ale skupiać się na sobie, nie podejmować obowiązków domowych, a nawet pracy zarobkowej, odznaczać się wyuczoną bezradnością, być lekkoduchem. $\mathrm{Z}$ osobą o takich cechach będzie trudno zbudować wspólnotę małżeńską. Często obowiązki będą spadać tylko na drugą stronę, która będzie pozbawiona wsparcia i pomocy ze strony współmałżonka. Natomiast wspólne z partnerem wykorzystywanie swoich zdolności dla obopólnego dobra, osiąganie wyznaczonych celów, posiadania podobnych ambicji i zainteresowań pozwolą na zacieśnienie więzi miedzy nimi, staną się przyczyną wspólnej satysfakcji ze związku, a także inspiracją dla nowych zamierzeń, co będzie wzmacniać relacje między współmałżonkami.

10 Zob. T. Rostowska, Dojrzałość osobowa jako podstawowe uwarunkowanie życia małżeńskiego i rodzinnego, w: Psychologia w służbie rodziny, red. I. Janicka, T. Rostowska, Łódź 2003, s. 49-50.

${ }_{11}$ Więcej na ten temat zob. S. Tykarski, Trudności $w$ relacjach $z$ teściami $i$ możliwości ich naprawy, „Teologia i Człowiek”, 26 (2014) 2, s. 193-207. 
Z zagadnieniem samorozwoju można także powiązać kwestie samowychowania. Osoba, widząc swoje niewłaściwe zachowanie, potrafi dokonać wglądu, przeanalizować swoje poczynania (jest ich świadoma), znaleźć ich przyczynę, podjąć środki naprawcze, przyznać się do błędu i zadośćuczynić. Również jest otwarta na przyjęcie oceny i uwag od innych osób. Praca nad sobą wiąże się z wzięciem odpowiedzialności za swoje zachowanie, jak również ogólniej - za całokształt wyglądu swojego życia oraz rodziny, którą się w przyszłości założy. W związku z tym samowychowanie staje się kolejnym wyznacznikiem dojrzałej osobowości ${ }^{12}$. Bardzo trudno jest bowiem budować relacje małżeńskie z kimś, kto nigdy nie widzi swojej odpowiedzialności za nieporozumienia czy kłótnie. Jeśli nie dostrzega swojego wkładu w zaistniałą sytuację konfliktową, to nie będzie chciał podjąć środków naprawczych, sądząc, że taki obowiązek leży tylko po stronie współmałżonka.

Następnym kryterium dojrzałej osobowości jest posiadanie zwartego światopoglądu, filozofii życia, hierarchii wartości, systemu zachowań etycznych i moralnych, wyznawania wiary. Istotne jest, by kandydat do małżeństwa odznaczał się posiadaniem zasad życiowych, które nie będą sprzeczne $\mathrm{z}$ etyką. Jeśli nupturient w rażący sposób narusza normy moralne lub tylko teoretycznie je wyznaje, to zachodzi prawdopodobieństwo trudności w relacjach małżeńskich. Kandydat nie będzie uznawał za nic zdrożnego kłamstwa, oszukiwania, nieszanowania i zdrady współmałżonka. Z tego powodu bardzo ważna jest kwestia spójności nupturientów pod kątem posiadanego światopoglądu i wyznawanych wartości. Niemałe znaczenie ma też wyznawanie wiary. Jeśli kandydaci różnią się diametralnie w tym względzie, czyli jedna ze stron jest religijna i praktykująca, druga zaś słabo lub w ogóle, to mogą na tym tle pojawiać się konflikty. Współmałżonek może stanowić przeszkodę w wychowywaniu dzieci w wierze, przyjmowaniu sakramentów, uczęszczaniu na liturgię niedzielną lub z okazji uroczystości kościelnych. Niekiedy wyśmiewanie praktyk religijnych może przyczynić się do poczucia przykrości i zranień u współmałżonka. Natomiast wyznawana wiara przez kandydatów do małżeństwa oraz praktykowanie po jego zawar-

12 Więcej na temat samowychowania zob. T. Kukołowicz, Wychowanie do samowychowania warunkiem osiągnięcia dojrzałej osobowości, w: Szkice o kształtowaniu osobowości, red. J. Kostkiewicz, Rzeszów 1997, s. 49-57; Z. Chlewiński, Dojrzałość: osobowość, sumienie, religijność, Poznań 1991, s. 32-38. 
ciu, może mieć realny wpływ na kształtowanie się dojrzałej osobowości. Zdaniem Chlewińskiego religia integruje oraz ukierunkowuje funkcjonowanie osobowości, a także spełnia następujące zadania: nadaje sens życiu, wyjaśnia znaczenie śmierci i cierpienia, pomaga interpretować różne zdarzenia związane $\mathrm{z}$ egzystencją, nadając im wartość, porządkuje hierarchię wartości, daje poczucie bezpieczeństwa i kształtuje zaufanie (co pozwala zachować psychiczną integralność), poprzez uczestnictwo w obrzędach religijnych osoba dokonuje swojej identyfikacji (autoidentyfikacja), jak również identyfikacji z grupą (wspólnotą kościelną), co umożliwia nawiązanie więzi międzyludzkic; religia pełni także funkcję autopsychoterapeutyczną, likwidując źródło napięć neurotycznych ${ }^{13}$. Można zatem powiedzieć, że kształtując osobowość religijną, kształtuje się dojrzałą osobowość. Ponadto małżeństwa wspólnie praktykujące wiarę wykazują większą trwałość, są mniej narażone na rozpad, co zwiększa możliwość osiągnięcia szczęścia

13 Zob. Z. Chlewiński, Wprowadzenie do psychologii religii, w: Psychologia religii, red. Z. Chlewiński, Lublin 1983, s. 73-75.

Dojrzała religijność czyli religijność personalna jest „angażującą formą przeżywania kontaktu z Bogiem osobowym. Człowiek jako podmiot relacji religijnej w partnerskim dialogu z Bogiem angażuje całe swoje «ja» w bezpośrednie i aktualne «Ty» Boga. W swoich aktach człowiek ten czuje się wolny i twórczy, świadomy swego celu i własnej chrześcijańskiej godności. Ma on świadomość, że tworzy swój stosunek do Boga i czuje się za to odpowiedzialny. Osoba Boga integruje cały świat wartości tego człowieka. Relacja między Bogiem i człowiekiem ma tu charakter wzajemnej dynamiczniej obecności i miłości. Jest ona centralną trwałą i ustabilizowaną wartością dla tego człowieka i nie niszczy przy tym jego otwartości na nowe wiadomości i doświadczenia.

Natomiast religijność apersonalna jest to forma przeżywania kontaktu człowieka z Bogiem, traktowanym na sposób «rzeczy», «instrumentu» zaspokajającego egotyczne potrzeby człowieka. Ma on najczęściej formę monologu. [...] Kontakt z Bogiem podporządkowany jest innym celom i ukierunkowany na osiągnięcie innych wartości niż sam Bóg. [...] Brak poczucia odpowiedzialności za stan tej relacji uwalnia go od twórczego jej pogłębienia i szukania dla niej nowych form wyrazu. Religia i Bóg stają się wartościami peryferyjnymi, zewnętrznymi i odizolowanymi od innych sfer życia”. R. Jaworski, Psychologiczna analiza religijności personalnej, „Zeszyty Naukowe KUL”, Rok XLI, nr 3-4 (163-164) 1998, s. 77-88.

$\mathrm{Na}$ temat powiązania religijności personalnej z satysfakcją w małżeństwie zob.

E. Kiełek-Rataj, Religijność personalna a satysfakcja z małżeństwa, „Family forum”, 3 (2013), s. 97-114. 
małżeńskiego ${ }^{14}$. Nie oznacza to, że więź religijna zabezpiecza małżeństwo przed trudnościami czy konfliktami, daje jednak większą siłę małżonkom do zmierzenia się z nimi i do konstruktywnego ich rozwiązania. Dynamiczne życie duchowe staje się dla małżonków źródłem stabilności, siły i nadziei. Z badań M. Wilson wynika, że „średnio 50\% małżeństw się rozwodzi; małżeństw, które zawarły sakramentalny związek w kościele - 30\%; małżeństw, które co niedziela chodzą wspólnie na Eucharystię - 2\%; małżeństw, które chodzą co niedziela wspólnie do kościoła i codziennie się modlą, rozwodzi się 1 na ponad $1500(0,07 \%)$ "15.

\section{KONTEKST PASTORALNY}

Rozważając kontekst pastoralny, warto zastanowić się, co można zrobić, by kształtować w kandydatach do małżeństwa dojrzałą osobowość. Odpowiedź nie jest prosta, a składa się na nią wielowymiarowość i długofalowość oddziaływań. Jednym z nich jest wychowanie i edukacja młodego pokolenia. Z pomocą przychodzi tu pedagogika. Dzięki pogłębianiu refleksji teoretycznej oraz przeprowadzanym badaniom empirycznym pedagodzy mogliby opracować system oddziaływań wychowawczych pomagających w kształtowaniu przez rodziców dojrzałej osobowości u dzieci ${ }^{16}$. Mogłoby się to dziać przy współpracy katolickich ośrodków naukowych $\mathrm{z}$ innymi uniwersyteckimi wydziałami pedagogiki.

${ }_{14}$ Zob. M. Ryś, Psychologia małżeństwa w zarysie, Warszawa 1999, s. 45; J. Rostowski, Zarys psychologii małżeństwa, Warszawa 1987, s. 102-103.

15 J. Pulikowski, Miejsce płciowości w miłości, Poznań 2009, s. 85. Inne źródło opierające się na tych samych badaniach podaje, że wśród małżeństw, które codziennie się modlą, rozwodzi się jedno na 1420. Zob. A. Rębacz, Odnawiamy małżeńskie śluby. Wywiad przeprowadzony przez Andrzeja Tarwida, „Tygodnik katolicki Niedziela”, 28 września 2008 R. 51 nr 39, s. 25. Na temat powiązania między zaangażowaniem religijnym a jakością małżeństwa zob. T. Rostowska, P. Żylińska, Stopień zaangażowania religijnego a poziom jakości małżeńskiej u partnerów, w: Psychologia rodziny. Małżeństwo i rodzina wobec współczesnych wyzwań, red. T. Rostowska, Warszawa 2009, s. 117-135.

${ }^{16} \mathrm{~W}$ środowisku rodzinnym kształtowanie dojrzałej osobowości „opiera się na zaspokojeniu najważniejszych potrzeb dziecka, takich jak: potrzeba miłości, bezpieczeństwa, akceptacji, kontaktu, samodzielności, twórczości, a także pomocy w interioryzowaniu właściwej hierarchii wartości”. G. Pyźlak, Recepcja przygotowania do małżeństwa w świetle badań narzeczonych, Lublin 2007, s. 139. 
Oczywiście zadanie wychowania do dojrzałej osobowości, choć przede wszystkim, to jednak nie odnosi się tylko do środowiska rodzinnego. Także inne, jak np. szkoła, mogłyby aktywnie zaangażować się $\mathrm{w}$ ten proces poprzez program zajęć chociażby $\mathrm{w}$ ramach godzin wychowawczych. Ze względu na obecność katechezy w szkole także i to zadanie spoczywa na barkach Kościoła. Diecezjalne wydziały katechetyczne mogłyby opracować program nauczania, który miałby na uwadze wychowywanie do dojrzałej osobowości. Takie przedsięwzięcia mają swoje miejsce $\mathrm{w}$ ramach przygotowania dalszego do małżeństwa, które według Jana Pawła II „zaczyna się już w dzieciństwie, w tej mądrej pedagogii rodzinnej, nastawionej na doprowadzenie dzieci do odkrycia siebie jako istot obdarzonych złożoną i bogatą psychiką oraz własną osobowością z jej mocnymi i słabymi stronami. Jest to okres, w którym powinno się zaszczepić szacunek dla każdej zdrowej wartości ludzkiej, tak w stosunkach międzyosobowych, jak i społecznych, z tym wszystkim co ma znaczenie dla kształtowania charakteru, dla opanowania i właściwego użycia własnych skłonności, dla sposobu widzenia i traktowania osób odmiennej płci itd. Ponadto wskazana jest, zwłaszcza u chrześcijan, mocna formacja duchowa i katechetyczna, która ukazałaby małżeństwo jako prawdziwe powołanie i posłannictwo [...]"17.

Niemałe znaczenie w realizacji zadania kształtowania dojrzałej osobowości mają również organizacje młodzieżowe zarówno o charakterze kościelnym, jak i świeckim. Takie grupy jak np. oaza, szkolne koła Caritas, Katolickie Stowarzyszenie Młodzieży, duszpasterstwo akademickie, harcerstwo, grupy charytatywne przez swoje programy formacyjne stanowią przestrzeń sprzyjającą kształtowaniu i rozwojowi dojrzałej osobowości u młodych ludzi. Potrzeba w tym dziele ochotnego i głębokiego zaangażowania duszpasterzy i ludzi świeckich wierzących, związanych z Kościołem, jak również współpracy z placówkami oświaty.

W tym miejscu należy zaznaczyć fakt, że nie można przekazać komuś tego, czego się samemu nie posiada. Parafraza słów św. Augustyna „karmię was tym, czym sam żyję" może być odniesiona do samych duszpasterzy, aby i oni kształtowali w sobie dojrzałą osobowość, by poprzez

\footnotetext{
17 Jan Paweł II, Adhortacja Apostolska o zadaniach rodziny chrześcijańskiej w świecie współczesnym „Familiaris Consortio”, Rzym 22 listopada 1981, nr 66.
} 
świadectwo życia i osobisty przykład mogli oddziaływać na tych, którzy zostali im powierzeni w misji pasterskiej zwłaszcza ludzi młodych ${ }^{18} . \mathrm{Ku}$ temu winna służyć solidna formacja seminaryjna przygotowująca do późniejszej autoformacji w tym względzie.

Ponadto istotne byłoby podjęcie przemyśleń związanych z tematyką katechez przedmałżeńskich odbywających się w ramach bliższego przygotowania do małżeństwa. Podczas tzw. kursów przedmałżeńskich można by było przekazać narzędzia do formowania dojrzałej osobowości, a nie tylko przekazywać informację, czym się ona charakteryzuje. Dlatego przygotowanie do małżeństwa winno być prowadzone na wysokim poziomie przez osoby kompetentne w dziedzinie życia małżeńsko-rodzinnego. Warto też zastanowić się nad stworzeniem dla osób przygotowujących się do małżeństwa możliwości przeprowadzenia testów, dzięki którym uczestnicy mogliby dowiedzieć się, czy posiadają dojrzałą osobowość, oraz poznać swoje deficyty lub płaszczyzny, na których dochodziłoby do trudności w budowaniu związku ${ }^{19}$. Dzięki temu otrzymaliby możliwość podjęcia działań korekcyjnych w swoim zachowaniu, potrzebnych w rozwiązywaniu ewentualnych konfliktów mogących się pojawić w przyszłym życiu małżeńskim. Również dzięki takim testom byliby w stanie poznać swoje zalety, mocne strony, które mogą być wykorzystane w pogłębianiu więzi małżeńskiej. Ponadto podczas katechez przedmałżeńskich prowadzący mogliby pomóc przeanalizować uczestnikom motywy zawarcia małżeństwa pod względem dojrzałości. Czas ten stawałby się dla kandydatów możliwością pracy nad własną dojrzałością osobową, nad emocjami, poznaniem siebie i partnera. Mógłby być też wykorzystany na rozwój umiejętności interpersonalnych i komunikacyjnych z uwzględnieniem ważkości znaczenia spójnego doboru pod kątem religijnym ${ }^{20}$. Widać zatem pilną potrzebę reorganizacji dotychczasowej formy katechizacji przedślubnej zarówno

18 Więcej na ten temat zob. A. Rynio, Autorytet osób znaczących $w$ kształtowaniu osobowości dojrzałej, w: Szkice o kształtowaniu osobowości, s. 59-72.

19 Przykładowym narzędziem jest skala dojrzałości małżeńskiej „SKALDOM” opracowana przez prof. Marię Ryś i współpracowników.

${ }^{20}$ Zob. J. Goleń, Motywy zawarcia małżeństwa sakramentalnego. Studium z duszpasterstwa rodzin $w$ świetle badań narzeczonych, Lublin 2013, s. 339-341, 343. Na temat znaczenia wspólnie wyznawanej wiary w życiu małżeńskim zob. S. Tykarski, Kryzys małżeński, s. 223-234. 
od strony merytorycznej (dobór tematyki i specjalistów), jak i formalnej (zmiana mało atrakcyjnej metody wykładowej na warsztatową). To działanie może zostać podjęte zarówno na szczeblu ogólnokrajowym przez odpowiednie władze kościelne, jak i na poziomie diecezjalnym.

Również podczas kanonicznego dochodzenia przedślubnego, czyli potocznie mówiąc „spisania protokołu z narzeczonymi”, duszpasterze mogą nawiązać do znaczenia posiadania dojrzałej osobowości u nupturientów, wykazując, jakie ma to przełożenie w życiu małżeńskim i jakie niesie ze sobą zagrożenie zawierania związku z osobą niedojrzałą. W tym celu zasadne jest przygotowanie odpowiednich materiałów, w których znalazłyby się informacje, czym jest dojrzała osobowość, jakie są jej kryteria i jak można ją konstytuować. Przygotowanie tego typu pomocy leżałoby w gestii Wydziału Duszpasterstwa Rodzin lub Krajowego Ośrodka Duszpasterstwa Rodzin Konferencji Episkopatu Polski. W przypadkach nadzwyczajnych duszpasterze podczas spotkania z kandydatami, widząc rażące deficyty osobowościowe, winni zachęcić do przemyślenia, a nawet odroczenia decyzji zawarcia małżeństwa ${ }^{21}$.

Nie można pominąć również możliwości formowania małżonków, zwłaszcza tych młodych, którzy niedawno weszli na drogę małżeńskiego życia. Warto byłoby organizować warsztaty, panele dyskusyjne, dni

${ }^{21}$ W podobnym duchu wypowiada się papież Franciszek, mówiąc: „Przygotowanie osób, które już się zaręczyły, kiedy wspólnota parafialna potrafi im towarzyszyć odpowiednio wcześnie, powinno dać im także możliwość rozpoznania niezgodności lub zagrożeń. Można w ten sposób zdać sobie sprawę, że nierozsądne jest postawienie na tę relację, aby nie narażać się na przewidywalne niepowodzenie, które będzie miało bardzo bolesne konsekwencje. Problem polega na tym, że początkowe olśnienie prowadzi do usiłowania ukrycia lub relatywizowania wielu rzeczy, unikania niezgodności i tak przesuwa się trudności na przyszłość. Narzeczonych należy pobudzać i pomagać im, aby mogli wyrazić to, czego każdy oczekuje od ewentualnego małżeństwa, swego sposobu rozumienia, czym jest miłość i zaangażowanie, czego pragnie od drugiej osoby, jaki typ wspólnego życia chce planować. Rozmowy takie pomogą dostrzec, że w rzeczywistości niewiele jest punktów wspólnych i że samo wzajemne zauroczenie nie wystarczy, aby utrzymać związek. Nic nie jest bardziej zmienne, niepewne i nieprzewidywalne niż pożądanie i nigdy nie należy zachęcać do decyzji o zawarciu małżeństwa, jeżeli nie doszło do pogłębienia innych motywacji, które dają tym zaręczynom realną szansę stabilności”. Franciszek, Posynodalna Adhortacja Apostolska "Amoris Laetitia” o miłości w rodzinie, Rzym 19 marca 2016, nr 209. 
skupienia, rekolekcje, podczas których przekazywałoby się wiedzę oraz umiejętności budowania relacji, rozwiązywania konfliktów, kształtowania postawy miłości, znaczenia oraz rozwoju religijności personalnej, wątku duchowości i wiary w życiu małżeńskim. Tematyka mogłaby także poruszać zagadnienia związane z trudnościami, jakie do tej pory napotkali młodzi małżonkowie.

Nie wolno zbagatelizować wątku związanego z pomocą małżeństwom, które przeżywają kryzys swojego związku, będący konsekwencją posiadania niedojrzałej osobowości przez współmałżonka. Z pomocą mogłyby przyjść diecezjalne ośrodki pomocy psychologicznej i psychoterapeutycznej, w których małżonkowie otrzymaliby fachową pomoc i wsparcie. Takie ośrodki można prowadzić przy współudziale organów władzy samorządowej. Paradoksem jest bowiem fakt, że w niektórych krajach więcej wydaje się środków na rozwody i ich skutki niż na przygotowanie do małżeństwa bądź na poradnictwo małżeńsko-rodzinne ${ }^{22}$.

Wyżej wymienione propozycje są przykładami realizowania wezwania, jakie mieści się w dokumencie „Służyć Prawdzie o Małżeństwie i Rodzinie", który mówi:

Zarówno przyszli małżonkowie, jak duszpasterze muszą mieć jasną świadomość, że przygotowanie do sakramentu małżeństwa nie może ograniczyć się do kancelaryjnych formalności, ale jest naprawdę priorytetowym działaniem duszpasterskim. Zarówno narzeczeni, jak duszpasterze muszą na nowo odkryć jego ważność. Niech przy tym jedni i drudzy pamiętają, że jakość przygotowania do małżeństwa decyduje w dużej mierze o przyszłym życiu małżeńskim ${ }^{23}$.

Długofalowe przygotowanie - jak poucza papież Franciszek - ma pomóc kandydatom

wykryć sygnały ostrzegawcze zagrożeń, na jakie relacja może napotkać, aby przed ślubem znaleźć środki pozwalające pomyślnie stawić im czoło. Niestety wielu przychodzi do ślubu, nie znając się nawzajem.

${ }^{22}$ Zob. R. Sztychmiler, Przygotowanie do małżeństwa w aspekcie osobowości kandydata, w: Osobowość kandydata do matżeństwa, red. R. Sztychmiler, Olsztyn 1999, s. 96.

${ }^{23}$ Konferencja Episkopatu Polski, Stużyć prawdzie o małżenstwie i rodzinie, Łomża 19 czerwca 2009, nr 98. 
Jedynie wspólnie się bawili, mieli wspólne doświadczenia, ale nie stawili czoła wyzwaniu, by ukazać samych siebie i nauczyć się, kim naprawdę jest druga osoba.

Zarówno przygotowanie bliższe, jak i towarzyszenie dłuższe, powinny przekonać narzeczonych, aby nie postrzegali pobrania się jako końca drogi, ale aby podjęli małżeństwo jako powołanie, które wymaga stanowczej i realistycznej decyzji, aby wspólnie przejść przez wszystkie próby i chwile trudne. Duszpasterstwo przedmałżeńskie i duszpasterstwo małżeństw powinny być przede wszystkim duszpasterstwem więzi, gdzie wnoszone są elementy, które pomagają zarówno w dojrzewaniu miłości, jak i w przezwyciężaniu chwil trudnych. Tym wkładem są nie tylko przekonania doktrynalne. Nie może się ono sprowadzać tylko do cennych bogactw duchowych, jakie Kościół oferuje zawsze, ale muszą to być także i drogi praktyczne, poradnictwo dobrze zakorzenione w realiach, strategie zaczerpnięte $\mathrm{z}$ doświadczenia, poradnictwo psychologiczne ${ }^{24}$.

Podsumowując, nie można zapomnieć o czym mówił Jan Paweł II, a mianowicie, że „przyszłość świata i Kościoła idzie przez rodzinę”25. „Rodzina zatem jest w strukturze duszpasterstwa rodzin pierwszym podmiotem oddziaływania apostolskiego"26. Znaczy to, że ma być głównym przedmiotem działalności pastoralnej, a nie tylko jednym z dystryktów duszpasterstwa ${ }^{27}$. Trzeba mieć również na uwadze, iż wszelkie działania duszpasterskie nie przyniosą natychmiastowego efektu. Mają one charakter długofalowy i wymagają wytrwałości oraz cierpliwości ze strony samych duszpasterzy, jak również zaangażowania, myślenia perspektywicznego, a także posiadania wizji duszpasterstwa małżeństw i rodzin, którą się $\mathrm{z}$ pasją podejmie.

${ }^{24}$ Franciszek, Posynodalna Adhortacja Apostolska „Amoris Laetitia” o miłości $w$ rodzinie, Rzym 19 marca 2016, nr 210-211.

${ }^{25}$ Jan Paweł II, Adhortacja Apostolska o zadaniach rodziny chrześcijańskiej w świecie współczesnym „Familiaris Consortio”, Rzym 22 listopada 1981, nr 75.

${ }^{26}$ Konferencja Episkopatu Polski, Dyrektorium Duszpasterstwa Rodzin, Warszawa 1 maja 2003, nr 7.

27 Zob. Komisja Episkopatów Europejskich do Spraw Rodziny i Życia, Dokument końcowy Sesji Przewodniczących Komisji Episkopatów do spraw Rodziny i Życia, Watykan 27-28-29 września 1999, nr 6, „Sprawy Rodziny”, 2000 nr 51, s. 92. 
Streszczenie. Niniejszy artykuł stanowi drugą część szerszego opracowania, które zostało opublikowane we wcześniejszym numerze periodyku „Teologia i Człowiek”, w którym scharakteryzowano wyznaczniki dojrzałej osobowości. Są nimi na przykład: realistyczne spostrzeganie rzeczywistości, umiejętność rozwiązywania problemów, nawiązywanie i utrzymywanie bliskich relacji z ludźmi, posiadanie dojrzałej emocjonalności, samorealizacja i samowychowanie, posiadanie zwartego światopoglądu, hierarchii wartości i przekonań religijnych. Niniejszy artykuł jest częścią swoistego dyptyku, opisując znaczenie posiadania dojrzałej osobowość u osób przygotowujących się do małżeństwa. Ukazane zostaną również negatywne konsekwencje mające wpływ na relacje małżeńskie, wynikające z posiadania niedojrzałej osobowości. Druga część opracowania zawiera postulaty pastoralne, mające na celu wyznaczenie przedsięwzięć duszpasterskich przyczyniających się do konstytuowania dojrzałej osobowości u kandydatów do małżeństwa. Szczególny akcent został położony na pomoc pedagogiczną rodzicom w wychowywaniu dojrzałej osobowości u dzieci, reorganizację katechez przedmałżeńskich, programu katechizacji, współpracy z ośrodkami oświaty, organami władzy państwowej i samorządowej. Przez wychowywanie i kształtowanie u młodych dojrzałej osobowości stwarza się im realną szansę budowania trwałych małżeństw, przeciwdziałając w ten sposób panującej współcześnie mentalności rozwodowej.

Słowa kluczowe: małżeństwo; relacje; osobowość; dojrzałość; dojrzała osobowość.

Abstract. The Importance of a Mature Personality for People Preparing for Marriage - A Psychological Sketch in a Pastoral Aspect. The present article is the second part of a broader study which has been published in the earlier issue of Theology and Man and presented the characteristics of indicators of mature personality The indicators include, among others, realistic perception of reality, problem solving skills, creating and maintaining close relationships with people, possessing mature emotionality, self-actualization, self-education, coherent worldview, hierarchy of values and religious convictions. The article forms a part of a diptych which describes the significance of mature personality for marriage candidates. It also presents negative consequences which influence relationships in marriage and result from immature personality. The second part of the article includes pastoral postulates whose aim is to delineate pastoral activities which may contribute to the formation of mature personality of marriage candidates. The emphasis is on pedagogical assistance for parents in formation of mature personality of their children, reorganization of pre-marriage programs, catechization and cooperation with educational authorities and state and local governments. Through education and formation of mature personality of young people it is possible to create a real chance of building lasting marriages and counteract modern divorce mentality.

Key words: marriage; relationship; personality; maturity; mature personality. 


\section{BIBLIOGRAFIA}

Chlewiński Z., Dojrzałość: osobowość, sumienie, religijność, Poznań 1991.

Chlewiński Z., Wprowadzenie do psychologii religii, w:, Psychologia religii, red. Z. Chlewiński, Lublin 1983, s. 10-76.

Field D., Osobowości małżeńskie, Warszawa 1996.

Franciszek, Posynodalna Adhortacja Apostolska "Amoris Laetitia” o miłości w rodzinie, Rzym 19 marca 2016.

Goleń J., Motywy zawarcia małżeństwa sakramentalnego. Studium $z$ duszpasterstwa rodzin w świetle badań narzeczonych, Lublin 2013.

Jan Paweł II, Adhortacja Apostolska o zadaniach rodziny chrześcijańskiej w świecie wspótczesnym „Familiaris Consortio”, Rzym 22 listopada 1981.

Jaworski R., Psychologiczna analiza religijności personalnej, „Zeszyty Naukowe KUL”, Rok XLI, nr 3-4(163-164) 1998, s. 77-88.

Kiełek-Rataj E., Religijność personalna a satysfakcja $z$ małżństwa, „Family forum”, t. 3 2013, s. 97-114.

Komisja Episkopatów Europejskich do Spraw Rodziny i Życia, Dokument końcowy Sesji Przewodniczacych Komisji Episkopatów do spraw Rodziny i Życia, Watykan 27-28-29 września 1999, nr 6, „Sprawy Rodziny”, 2000.

Konferencja Episkopatu Polski, Dyrektorium Duszpasterstwa Rodzin, Warszawa 1 maja 2003.

Konferencja Episkopatu Polski, Służyć prawdzie o małżeństwie i rodzinie, Łomża 19 czerwca 2009.

Kukołowicz T., Wychowanie do samowychowania warunkiem osiągnięcia dojrzałej osobowości, w: Szkice o kształtowaniu osobowości, red. J. Kostkiewicz, Rzeszów 1997, s. $49-57$.

Laskowski J., Trwałość wspólnoty małżeńskiej. Studium socjopsychologiczne, Warszawa 1987.

Oleś P. K., Psychologia człowieka dorosłego, Warszawa 2012.

Osobowość kandydata do małżeństwa, red. R. Sztychmiler, Olsztyn 1999.

Psychologia religii, red. Z. Chlewiński, Lublin 1983.

Psychologia rodziny. Małżeństwo i rodzina wobec współczesnych wyzwań, red. T. Rostowska, Warszawa 2009.

Psychologia w służbie rodziny, red. I. Janicka, T. Rostowska, Łódź 2003.

Pulikowski J., Miejsce płciowości w miłości, Poznań 2009.

Pyźlak G., Recepcja przygotowania do matżeństwa w świetle badań narzeczonych, Lublin 2007.

Rębacz A., Odnawiamy małżeńskie śluby. Wywiad przeprowadzony przez Andrzeja Tarwida, „Tygodnik katolicki Niedziela”, 28 września 2008 R. 51 nr 39, s. 25.

Rostowska T., Dojrzałość osobowa jako podstawowe uwarunkowanie życia małżeńskiego $i$ rodzinnego, w: Psychologia w służbie rodziny, red. I. Janicka, T. Rostowska, Łódź 2003, s. 45-88. 
Rostowska T., Żylińska P., Stopień zaangażowania religijnego a poziom jakości małżeńskiej u partnerów, w: Psychologia rodziny. Małżeństwo i rodzina wobec współczesnych wyzwań, red. T. Rostowska, Warszawa 2009, s. 117-135.

Rostowski J., Zarys psychologii małżenstwa, Warszawa 1987.

Rynio A., Autorytet osób znaczących w kształtowaniu osobowości dojrzałej, w: Szkice o kształtowaniu osobowości, red. J. Kostkiewicz, Rzeszów 1997, s. 59-72.

Ryś M., Psychologia małżństwa w zarysie, Warszawa 1999.

Szkice o kształtowaniu osobowości, red. J. Kostkiewicz, Rzeszów 1997.

Sztychmiler R., Przygotowanie do małżeństwa w aspekcie osobowości kandydata, w: Osobowość kandydata do małżeństwa, red. R. Sztychmiler, Olsztyn 1999, s. 81-105.

Tykarski S., Kryzys małżeński jako wyzwanie dla duszpasterstwa. Studium teologiczno-pastoralne, Toruń 2015.

Tykarski S., Negocjacje jako sposób rozwiązywanie konfliktów małżenskich i rodzinnych, „Teologia i Człowiek”, 30 (2015) 2, s. 151-170.

Tykarski S., Trudności w relacjach z teściami i możliwości ich naprawy, „Teologia i Człowiek", 26 (2014) 2, s. 193-207.

Wojciszke B., Psychologia miłości, Gdańsk 2012.

Wolicki M., Dojrzała osobowość. Dojrzałe sumienie, Wrocław 2000. 